\title{
University Presidents and Politicians
}

\author{
CLAUDE T. BISSELL*
}

\begin{abstract}
It is customary to think of the ideal university president as being necessarily opposed to the methods and aims of the public politician. If, as Thorstein Veblen argued, he adopts those methods and aims, he betrays the university and becomes, in effect, the head of a corporation or a minor state. It is the argument of this paper, however, that the president can lead and direct the University only if he accepts a political role, and strives to establish a high place for the university among public priorities. At the University of Toronto (and at other Canadian universities in varying degrees and in varying ways), the president was not able to play this political role until the great expansion of the 'sixties. Then, the need for long-range planning brought the presidents into the political arena. At the same time, internal stresses led to the creation of more representative governing bodies within the universities, and made the president a political figure who must strive to achieve a central alliance within the academic community.
\end{abstract}

\section{RÉSUMÉ}

\section{Les présidents d'université et les politiciens}

On a l'habitude de penser que le président d'université idéal soit nécessairement opposé aux méthodes et aux objectifs des politiciens publics. Si, tel qu'a raisonné Thorstein Veblen, il adopte ces méthodes et ces objectifs, il trahit l'université et devient, en effet, le chef d'une corporation ou d'un état mineur. Cet essai, cependant, suit le raisonnement suivant: le président est en mesure de guider et de diriger l'université seulement s'il accepte un rôle politique et s'il oeuvre pour que l'on accorde à l'université un rang important parmi les priorités publiques. Á l'Université de Toronto (ainsi qu'à d'autres universités canadiennes à de divers degrés et dans de diverses facons), le président n'avait pas été en mesure de jouer ce rôle politique jusqu'au dévéloppement vaste et rapide des années 60 . À ce moment-là, le besoin de planification à long terme a amené les présidents d'université dans l'arène politique. En même temps, les tensions internes ont mené la création des corps gouvernants plus représentatifs à l'intérieur de l'université et ont poussé le président

\footnotetext{
* University Professor, University of Toronto
} 
à devenir un homme politique obligé d'oeuvrer pour la réalisation d'une alliance centrale à l'intérieur de la communauté académique.

When we think of politicians, we think, first of all, of those who live and work outside the university. The popular connotation of the word, which carries with it, at best, a touch of knowing cynicism and, at worst, an element of the dark and circuitous, discounts its noble lineage. For politicians are people who engage actively in politics, and politics in a democracy is the art of ordering a society so as to enable the individual to live in peace, security, enlightenment and freedom - surely one of the most honourable of all activities, and not one that should create a barrier between politicians and the heads of institutions of higher learning. But implicit in the title, and sustained by history, is the existence of a tension between politicians and universities. It is, first of all, the tension that inevitably exists between those who make the final decisions and those who must obey them. And when a university has been, as almost all the universities of Canada have been in varying degrees, dependent upon the state (usually the provincial government), for the means to carry on its work, the tension is persistent. But the tension goes beyond the provision of resources; it is not simply a question of the son denied the allowance he believes he requires for the full exercise of his manifold talents, or, perhaps more accurately, the head of an influential department in a corporation denied the budget he believes is essential for the carrying out of his crucial task; the tension arises from a difference in methods and goals. The politician finds that, more often than not, he must make short-term decisions. He cannot wait for all the evidence to come in, or, even for a considered review of the available evidence. He must make decisions and act upon them, and he subscribes to the military injunction that any action is better than no action. Moreover, he must pay attention to the opinions and prejudices of those who elected and, he hopes, will elect him when, in one, two, three, or four years he again hazards his fortunes at the polls. Insofar as the President of a university is an academic and speaks for academics he will bring a different perspective to the examination of events. Insofar as he is an academic, he believes that he should wait patiently for the full accumulation of evidence before he makes a decision, and he sees himself not only as a citizen of his province and Canada, but of an international world of scholarship. Theoretically, then, as scholar he brings the perspective of time and universality to the contemplation of events. Certain qualifications to this serene picture enter the mind. The academic is usually concerned with past events. The evidence is in, and conveniently stored, and whatever he says can have no effect upon what has happened. And when he pronounces upon contemporary events, whether it be a new novel, the phenomenon of stagflation, the extent of energy resources, or the prospects of a political party, his judgments do not have the cool infallibility that the style implies.Perhaps a more basic difference between the politicians and the president is that the former does not need to get approval at the ballot box at regular intervals. But there are qualifications even here. For a period in the sixties university presidents were subjected to regular trials as unpredictable as an election and as emotionally charged as a Chinese people's court. And, recently, with the 
widespread acceptance of a terminal presidency, the incumbent has the feeling that time, with its inescapable demands, is always at his back.

So far I have used the term "politicians" to describe those who work on a big public scale and for whom universities are a part, and only a minor part, of the complicated social terrain they must keep in mind. But the university is also a world of its own, in recent times like a small, self-contained state. And it has a political life of its own. Here the role of the president changes. He is now the principal politician, concerned with the interrelation of parts, frequently attempting to shape the whole in accordance with a general plan. In this context the academic spokesman tends to disappear into the politician; and academic literature on the president-politician is even gamier than it is on the common variety of public politician. Here is a passage where John Langton, elected Vice-Chancellor of the struggling University of Toronto in 1855 , a position that carried a salary and considerable authority, writes uninhibitedly about the Rev. John McCaul, who was then President of University College, the closest office to the Presidency of University.

Dr. McCaul is no doubt a first rate scholar and a very clever man and he has one element fitting him for command that whether it is by bullying or by compromising or by artful countermining he never loses sight of the main object - to have his own way in the end; but he is absolutely deficient in the talent of order. Partly perhaps it is design. The end he always keeps in view, the means he is quite unscrupulous about and provided a thing will serve his turn in the end he cares not for its being suitable to the present state of affairs. No matter how heterogeneous or inconsistent with each other the materials may be, if he has or thinks he has the clue by which he can fit each of them into some place in his proposed building they will serve his turn. You may think I am prejudiced against the man because we have been brought into rivalry, but I formed my opinion of him very early in the day and those that know him best entertain the same. Whilst I was writing the previous page I had a visit from Dr. Wilson one of our Professors and, the conversation turning on McCaul, he warned me for the fiftieth time to beware of him and he added: - "if he opposes you you may be safe enough by fighting it out, but if ever he entirely agrees with you and appears to go cordially with you, beware, he will trip you up if he can." I omitted one trait of McCaul's - when a man has such complicated plans on his hands he can rarely be certain what turn things may take and he very rarely commits himself so far to an opinion that he cannot withdraw from it, or does a thing so effectually that it cannot be undone. If he does not see clearly how it will work in, he had rather do nothing and wait the course of events.

At the heart of the internal political problem in the university is always the question of finance, and this in turn has always been closely related to an outside force of a restrictive and complicated nature. For most of the nineteenth century it was religious sectarianism. McCaul, and even more persistently and aggressively, his successor, Sir Daniel Wilson, sought by all the means in their power to preserve the University endowment against the claims of sectarian colleges. After the achievement of federation and the establishment of firm business control by the University of Toronto Act of 1906, a major internal responsibility 
of the President became the demonstration that the University was being run on sound business principles.

Thorstein Veblen's The Higher Learning in America, which was published in 1918, but meditated upon and partially written around the time of his great classic, The Theory of the Leisure Class (1899), was, in large part, a picture of the businessman-president, and, given Veblen's gift for unbuttoned invective, an unflattering one. The president becomes an embodiment of the politician in his crudest and unloveliest form: a director who is yet servile to his financial masters; an indifferent scholar who protests his devotion to research and high academic standards. As the book moves forward the portrait of the businessman-president - Veblen calls him a Captain of Erudition - becomes increasingly darker and menacing. At first the tone is judicious, objective, with only an icy undercurrent of disapproval.

He must be a strong man; that is to say, a capable man of affairs, tenacious and resourceful in turning the means at hand to account for this purpose, and easily content to let the end justify the means. He must be a man of scrupulous integrity, so far as may conduce to his success, but with a shrewd eye to the limits within which honesty is the best policy, for the purpose in hand. $\mathrm{He}$ must have full command of the means entrusted to him and full control of the force of employés and subordinates who are to work under his direction, and he must be able to rely on the instant and unwavering loyalty of his staff in any line of policy on which he may decide to enter. He must therefore have free power to appoint and dismiss, and to reward and punish, limited only by the formal ratification of his decisions by the board of directors who will be careful not to interfere or inquire unduly in these matters, - so long as their strong man shows results.

By the final chapter, the thin mask of objectivity has been removed. The qualifications for a university presidency are now rather similar to those for a ward boss (although, it should be noted, for a ward of affluence and respectability).

Among the indispensable general qualifications, therefore, will be a "businesslike" facility in the management of affairs, an engaging address and fluent command of language before a popular audience, and what is called "optimism," -a serene and voluble loyalty to the current conventionalities and a conspicuously profound conviction that all things are working out for good, except for such untoward details as do not visibly conduce to the vested advantage of the well-to-do businessmen under the established law and order. To secure an appointment to executive office it is not only necessary to be possessed of these qualifications, and contrive to put them in evidence; the aspirant must ordinarily also, to use a colloquialism, be willing and able to "work his passage" by adroit negotiation and detail engagements on points of policy, appointments and administration.

Veblen reserves his sharpest invective for the businessman-president's oratorical accomplishments, which are employed to assure the outside world that the university is dedicated to morality and solvency.

So that an executive who aspires to do his whole duty in these premises will become in some sort an itinerant dispensary of salu tary verbiage; and university presidents have so come to be conventionally indispensable for the effusion of graceful speech at all gatherings of the well-to-do for convivial deliberation on the state of mankind at large. 
A delightful footnote to this portrait of the businessman-president is given by an old student of Veblen - Stephen Leacock. Dr. Boomer, the president of Plutoria University, in Arcadian Adventures with the Idle Rich, is a comic version of Veblen's moral satire. Dr. Boomer combines a contempt for the staff with a respect for wealth, and devotes most of his time to attracting wealth to the University. He thus describes to a prospective donor some of the wealthy benefactors of the University, who have been commemorated in "bronze busts of men with Roman faces and bare necks, and the edge of a toga cast over each shoulder."

\begin{abstract}
"A splendid group of men, are they not?" said the president. "We own them much. This is the late Mr. Hogworth, a man of singularly large heart." Here he pointed to a brooze figure wearing a wreath of laurel and inscribed Gulielmus Hogworth, Litt. Doc. "He had made a great fortune in the produce business, and wishing to mark his gratitude to the community, he erected the anemometer, the wind-measure, on the roof of the building, attaching to it no other condition than that his name should be printed in the weekly reports immediately beside the velocity of the wind. The figure beside him is the late $\mathrm{Mr}$. Underbugg, who founded our lectures on the Four Gospels on the sole stipulation that henceforth any reference of ours to the four gospels should be coupled with his name."
\end{abstract}

"What's that after his name?" asked Tomlinson.

"Litt. Doc.?" said the president. "Doctor of Letters, our honorary degree. We are always happy to grant it to our benefactors by a vote of the faculty."

Leacock's Dr. Boomer may be a little reminiscent, particularly in his dramatic use of Latin tags, of Sir William Peterson, classicist and president of McGill University during the first part of Leacock's academic career. But the McGill associations would be apparent only to a few Canadian readers with inside knowledge. Leacock clearly had in mind, as did Veblen, the great, private institutions in the United States. In the United States there were vast capital accumulations and weal thy men prepared, under persuasion, to shift some of their capital to the universities. It is difficult to transfer the Veblen and Leacock indictment to Canada, particularly to Toronto, where the two presidents whose tenure of office spanned most of this century until the end of the second world war, Sir Robert Falconer and Dr. Henry Cody, revived the clerical tradition that had begun with Strachan and McCaul.

Veblen's attack on the businessman-president, the Captain of Erudition, was conducted from a high, austere position. He disapproved of the drift of the university towards magnitude by the steady accretion of professional faculties (a process that was to result in the multiversity of the nineteen sixties), and the consequent delight of university administrators in statistical analysis. In this he was perceptive and accurate. But he also disapproved of the very concept of the American university (which, in a modified form, was also the Canadian) as essentially an undergraduate arts college to which was then added professional schools on a parallel basis and, above them all, a graduate school. To him the proper university was the graduate school alone, a group of scholars pursuing "esoteric knowledge" out of a sense of 'idle curiosity' in the campany of young scholars similarly motivated. Such a university didn't need a president, let alone a businessman-president with a talent for popular oratory, nor indeed any administrators at all. Veblen's concept was an 
academic utopia, a green and pleasant place for scholars, but not the sort of institution that would find welcome and support in a complex, expanding society. And the reality the diverse, many-purposed university that served both the short-term and long-term needs of society - did require central direction. It was just as well if the president had some of the business virtues that Veblen so deeply despised - a sensitivity to the probable outcome of a statistical pattern and a knowledge of where, at a given time, money could be most effectively spent. But beyond this, he should have interests and attitudes that carry him beyond institutional politics to the world of public politics, where the university is an integral part of any social design.

It has not been customary to include 'political sagacity' among the list of presidential 'virtues'. In a tribute to Sir Robert Falconer, Malcolm Wallace listed these virtues (with the implication that Sir Robert had all of them). They were "scholarship, character, good judgment, diplomatic skill, an instinct for justice, a capacity for dignified and effective conduct of public occasions" ("The Man and his Interests", Univesity of Toronto Quarterly, XIII, No. 2 (Jan. 1944), 149). It would never have occurred to him (or to any other academic commentator then or since) to have added skill as a politician. I would suggest, however, that political skill always has been a necessary quality for the university president. The unsavoury connotation of the word in an academic context derives from the fact that the president was, until recently, a hobbled politician, denied the chance to meet public politicians on their own ground, confined to the intense, tropical environment of the university.

My simple thesis is that the effective university president must be a politician free to deal with other politicians; that the conditions for full presidential political activity did not develop in Canadian universities until the early "sixties of this century; that, before. that, both the position of the university and the role of the president ruled out free politicial activity, and turned the president into a minor, faintly exotic satrap. If involvement in politics stains the white radiance of the presidential image, that is a small matter. For it is essential that the president be free to work with politicians, who must be responsive to opinion therefore, susceptible to persuasion, and not be restricted to bureaucrats, who tend to create their own self-enclosed world and resist any changes in it. But political freedom for the Canadian president was long delayed because he was a person with little power working in an institution that had little power to bestow on him.

The earliest English-speaking Universities: Dalhousie, King's College, the University of New Brunswick, McGill, Queens, and Toronto had, in the opinion of their founders, a very specific place in the social scheme. Robin Harris in his recent and authoritative A History of Higher Education in Canada 1663-1960 cites two passages that set the tone of the earliest ventures in higher education. The first is an address to Sir Guy Carleton, Governor-in-Chief of British North America, sent to him in 1783 by five clergymen still resident in New York.

"The founding of a College or Seminary of learning on a liberal plan in that province where youth may receive a virtuous education and can be qualified for the learned professions, is, we humbly conceive, a measure of the greatest consequence, as it would diffuse religious literature, loyalty and good morals among His Majesty's subjects there. If such a seminary is not established the inhabitants will have no means of educating their 
sons at home, but will be under the necessity of sending them, for that purpose either to Great Britain or Ireland, which will be attended with an expense that few can bear, or else to some of the states unfavourable to the British tradition."

The second letter, four years later, is from Bishop Mountain, who was to be a founder of McGill, to the lieutenant-governor of Quebec.
"Let me be permitted, then, to suggest the danger which may result to the political principles and to the future character as subjects of such of our young men among the higher ranks as the exigency of the case obliges their parents to send for classical education to the colleges of the United States. In these Seminaries, most assuredly, they are not likely to imbibe that attachment to our constitution in Church and State, that veneration for the Government of their country, and that loyalty to their King, to which it is so particularly necessary in the present time to give all the advantages of early predilection in order to fix them deeply both in the understanding and the heart."

The universities, in short, were conceived of as important political weapons. They stood in the front line of the counter-revolutionary attack. They were to preserve class divisions, constitutional monarchy, and sound moral principles against the threat of American revolutionary subversion. They were the creations - not so much of the state, particularly in Upper Canada had only a shadowy existence - as of a small privileged group who embodied authority in the colony - the ecclesiastical hierarchy of the Church of England and the officials - chiefly officers in the British forces, minor aristocrats, and bureaucrats versed in the ritual of the law. An austere classical curriculum followed inevitably from the concept of the social function of the university. Modifications in the direction of a less exclusive university, with expanded and more flexible curriculum, came rapidly enough, from the evangelical pragmatism of an Egerton Ryerson, and the faith in the redemptive power of education was experienced by Scotsmem like Thomas McCulloch of Pictou Academy and Dalhousie University, and his disciples, William Dawson of McGill and George Grant of Queens. But the original idea of the university did not easily disappear from men's minds. Thomas Chandler Haliburton, writing at the middle of the century, commented on the public distrust in Canada of the universities.

In Canada, there is an unfriendly feeling toward these institutions, which people who play upon popular prejudice or ignorance, endeavor to foster, by representing them as engrossed by the sons of the rich, who are able to pay the expense of their own instruction, without assistance from the public treasury; and that all that is thus bestowed, is so much withdrawn from the more deserving but untrained children of the poor.

As the basis of government became more popular, the universities, at the outset bastions of the state, retreated into a genteel obscurity, except when sectarian passions were aroused over the division of the endowment. The British North America Act of 1867 assigned education to the provinces. The fathers of confederation had primary and secondary school in mind, since the universities, although numerous for a nascent nation (there were 18 degree-granting institutions in 1868), seemed to belong to a private world of religious sectarianism and individual philanthropy. The provinces now became the official guardians, but they looked upon the universities as being outside the official state family. 
A financial history of the University of Toronto down to the end of the second world war would make dismal reading, and there is no reason to think that the history of other Canadian universities would be brighter. The Federation Act of 1887 may have been a political and educational triumph, but it did not revitalize financial policy. The provincial government continued to deny the right of the university to share in the consolidated revenue of the province; the cynical assumption was that the university had been endowed by the crown, "and that this should, apparently, suffice it for all time to come" (Wallace W. Stewart, A History of the University of Toronto 1827 - 1927, U. of T. Press, 1927, 159). In 1901 the government relented in a small way under the pressure of the newly organized alumni association, and made some minor concessions. The financial recommendations of the 1906 Commission (which were accepted by the government) ushered in a brief period of security. The principal recommendation was that the University should receive on an annual basis a sum equal to fifty per cent of the average receipts from succession duties over a period of three years - a principle that gave immediate solvency and an assurance of increasing revenue as the province grew and the university grew with it. But the new policy was abruptly abandoned by the government in 1914, and a limit of $\$ 500,000$ placed on the University's share in succession duties. A commission appointed in 1920 to make recommendations about finance reaffirmed the 1906 recommendation, but the government did not accept it. It was, of course, forced to make ad hoc grants above the $\$ 500,000$ to enable the university to survive. But "over the ensuing 20 years the amount of the annual grant averaged $\$ 1,500,000$, approximately one-third the amount that would have been allocated had the succession duty formula been followed". (Harris, 362.) Government policy was no doubt shaped by the growth of Queen's and Western, their consequent claims on government support, and the fear that a generous treatment of Toronto would encourage lively expectations elsewhere. The result was a long period of financing that was both inadequate and quixotic, in which the accidents of personal association and political sympathy played a large part. It is a miracle that the University of Toronto established itself during the 20's and 30's as an important centre of scholarship comparable with the best American state universities, some of which received government grants twice as great.

The inadequacy of financial support up until the end of the second world war was, in some measure, a reflection of the comparative obscurity of the universities in the broad political picture. The universities were thought of as élite institutions, graceful adornments of polite society, necessary adjuncts to law, religion, and education. There was no movement in nineteenth century Canada to link the universities with social need, such as there was in the United States following the passing of the Morrill Act in 1862, which provided land grant endowments for state universities with a bias towards agriculture and the mechanic arts. The initial move towards advanced work in agriculture and engineering came from professional societies. The universities were content to concentrate on undergraduate instruction in arts (which had many advantages, most notably the eventual development of a strong system of honour courses) and both graduate studies and research were neglected until well into the twentieth century. The universities thus had little basis for an appeal to society: a limited enrolment which never rose until the second world war to more than $4 \%$ of the college age group; a belated recognition of the need for professional education in engineering, agriculture, and medicine; and a weak tradition in scholarship and research. 
If the university carried little weight with the politicians, its official spokesman, the president, carried even less. To begin with, the office of the President of the University of Toronto did not really exist until 1892 and was not clearly defined until 1906. Strachan was president of King's College, McCaul of University College (except for the period from 1850-53 when he was designated president of a shadowy university). Wilson was also President of University College, but the term 'president' referred only to his chairmanship of the University Council created after the Federation Act of 1887 . London finally emerged as president of the University in 1892, but he had little authority. The report of the 1906 Royal Commission sums up with the hopeless position of the president the measureal restraint of secretarial prose: "At present when appointments are made by the LieutenantGovernor in Council, when the purse is controlled by the Board of Trustees, when the Senate, with the Vice-Chancellor as Chairman, directs academic policy, and the President is also one of the teaching staff, the Presidency is not made an office of sufficient importance in the University."

The major achievement of the University of Toronto Act of 1906, which turned the recommendations of the report into legislation, was to bring together academic responsibility in the office of the president, in particular, to give him the sole power to recommend academic appointments. Although such recommendations could be turned down by the newly created Board, the Board never to my knowledge exercised this authority. On the other hand, the Board was given complete control over the finances of the University. All the detailed financial decisions, it is true continued to be made by academics. The financial power of the Board operated in two broad areas: decisions about physical expansion; and the arrangements with the provincial government for the annual grant. Both of these were crucial, particularly the latter.

The system of divided authority, of two adjoining kingdoms each with its acknowledged sovereign, was most carefully articulated under the chairmanship of Eric Phillips, who was chairman from 1945 to 1964 . He instituted the position of Comptroller (later to develop into a Vice-President), the senior financial officer who reported directly to the Chairman. Phillips had been appointed by George Drew, the Prime-Minister of Ontario, and he interpreted his role as that of the head of a Crown Corporation, enjoying a good deal of autonomy, but ultimately responsible to the government for efficient and economical management. He reserved the sole right to discuss high financial matters with the PrimeMinister (who, at this time, seemed to be the only minister actively concerned with the universities); and given his close association with Mr. Drew, this was a happy arrangement for the University of Toronto. When I entered the President's office in 1948 as assistant to Sidney Smith, the Phillips system was firmly established and was working smoothly. It was based on an entente between the Chairman and President, not, it seemed too difficult to maintain, since Eric Phillips had wide intellectual interests, was deeply committed to the University, and was sympathetic to Sidney Smith's academic goals. (And devotion to the University and sympathy with the presidential academic policy characterized the attitude of Phillips' successors on the old Board - Henry Borden and O.D. Vaughan.) It was understood that the Chairman would be the sole political emissary and that the President would not venture beyond his academic kingdom. Eric Phillips had a natural talent for irony, which ranged from the relaxed and benign to the sharp and sardonic. He liked to talk about the heavy burden he carried in dealing with Queen's Park politicians, who were, he implied, wily and materialistic fellows, who could be understood and dealt with only by a business 
man. The president was, thereby, insulated from this dark world of intrigue, free to speculate and plan in a high-minded, academic manner.

Although the 1906 Act gave the President great powers, and prepared the way for a new age of tranquillity and accomplishment under Falconer, Cody, and Smith, it removed him completely from the political arena. He was, indeed, less a political figure than he was in the nineteenth century when, although constantly frustrated by checks and counterpowers, he could, in an emergency, go directly to the political centre, pound on the table, and demand justice for the university.

In one area the president did enjoy a high degree of political freedom - in the national scene. A national organization for Canadian universities had been established in 1916, and Sir Robert Falconer had been one of its founders. It was a remarkable body in that it brought together all the Canadian universities, large and small, sectarian and secular, English and French. Although it was essentially a deliberative body - and for many years preferred to be known as a 'conference' - it did form a common front on federal financial measures that promised some additional help to the universities. When in 1951, as the result of recommendations of the Royal Commission on the National Development in the Arts, Letters, and Sciences, the federal government began a system of supplementary per capita grants to the universities, the Conference changed its name to Association and became, on a high plane, of course, a lobbying and pressure group. The 'fifties and the early 'sixties were the period of the national conference designed to reveal both the plight and the centrality of the universities, and of deputations to see the Prime-Ministers - Mr. St. Laurent, Mr. Diefenbaker, and Mr. Pearson - and their ministers of finance. It is well to remember, in these days of communitarian and provincial zeal, that it was the federal government that took the initiative in recognizing the need for a comprehensive approach to the problems of higher education, and that it was a federal prime-minister from FrenchCanada, Louis St. Laurent, who set before the country the high humanistic goal of the university.

The presidential involvement in federal politics (and both Sidney Smith and I gave a large proportion of our time to these matters) was not looked upon as a violation of the understanding between Chairman and President that grew out of the 1906 Act. The real battle ground was still Queen's Park, not Ottawa, and at Queen's Park, for Toronto, the Chairman was in command. But events were forcing a change. The Province had been doing its own study of the financing of higher education and was startled by the figures that emerged; at the same time, almost every population centre in the province was doing a study of its needs in higher education, and was convinced that a college or university (the distinction was rarely made) should be forthwith set up in its principal town, where a beautiful site was available and a committee of senior citizens was eager to start a financial campaign. The deeper involvement of the province in higher education inevitably brought about a change in the political atmosphere. There was, first of all, the sudden elevation of higher education to a position of public visibility; it became, in short, one of the priorities in political action. But the province had no facilities for planning the great expansion that was clearly imminent. It needed the knowledge, and techniques that had been developed in the universities, and, to its great credit, it turned to the universities for support and direction. This, in turn, meant a sudden elevation in the position of the President. He, not the Chairman, was the key to the knowledge and techniques. No Chair- 
man could possibly have the time to explore these complicated problems, and besides, his horizon was bounded by the individual institution.

Before the presidents could function effectively on this new political front, they had to resolve some vexatious problems. Presidents had worked together easily on the national scene, but, in that area, there was the softening fact of distance and unfamiliarity. But in the provinces - this was certainly true of Ontario with the largest number of universities, shortly to be greatly expanded - no tradition of cooperation and consultation existed. Presidents walked serenely and carried a deep suspicion of each other. Add to this the clash between the old and the new, the haves and the have-nots (shortly to turn into the solid state and the exploding) and presidents, now breathing a heady atmosphere of global decision-making, were reluctant to share it. There was a sudden revival of the old monarchical presidency: the presidents were the only legitimate spokesmen of official university bodies, and their authority could not be divided. But gradually a provincial Council was formed, in which academic representatives joined presidents, and tough decisions were made often against the interests of individual institutions.

The Council was successful in persuading the government to adopt measures that would reduce the possibility of arbitrary government action. It won acknowledgment of the concept of the buffer committee, upon which the British grants committee was based, a non-government body with substantial academic representation. It also convinced the government that the administration of universities should not be merged with the administration of primary and secondary schools and that a separate ministry should be established. These were important concessions, although there were recurrent doubts about their effectiveness. Did the buffer committee have a genuine independence or was it a means of giving government action a specious appearance of large-minded democratic cooperation? Was the Ministry of Colleges and Universities sufficiently important to command attention in the cabinet? Originally it was occupied by William Davis, who retained his post of Minister of Education, and given his sympathetic understanding of the universities and his imminent elevation to the premiership, this was all to the good. But subsequent appointments moved in and out of the ministry with unbecoming speed with just enough time at their disposal to master the prejudices of their predecessors.

Still, on balance, the presidents and their academic associates had reason to be happy about what they accomplished on the provincial plane. This was my impression in 1971 when I left office, and the subsequent history of the Council strengthens it. When Dr. Macdonald, the executive director, retired recently, he set down what he believed to be the achievements of the council.

(1) [The universities] have accommodated to more rigorous constraint than other groups in the public sector through their own ingenuity, and with more fair-minded recognition of the economic realities facing the provinces than other groups.

(2) The universities have cooperated effectively in major areas where cooperation is advantageous. e.g. the Ontario University Application Centre which I believe to be the best, the most efficient and the most economical operation of its kind in the world; the automated network of library services which is the most sophisticated on this continent and probably in the world; the universities have at great cost in money, time, effort, and pride exposed their graduate programs to the rigours of external evaluation by world scholars. 
At the same time that the president was released to play a political role outside his own institution, he found that within he was still rigidly confined in his actions. The 1906 Report made crystal clear where his responsibilities lay. "We believe", said the Report, "that the Governors, as representing the Crown, should select the President. As their appointment for short terms insures their acceptability to the public, [in practice, these 'short terms' were automatically renewed] so he, owing his appointment to them, must work in harmony with them, and be amenable in all respects to their supervision. The test of his success as an administrator will be his ability to secure the co-operation of the Governors since, lacking their ratification of his acts, all his efforts must be futile". In short, the president appointed by the governors was responsible exclusively to them. Of course, it was to his advantage to maintain good relations with the Senate, which was the official voice of the faculty, and his political task, insofar as politics is the art of accommodating powerful and potentially antagonistic groups, was to avoid clashes between Senate and Board. But in the post-second world war university, this was a limited task that was becoming increasingly unreal. Other powers were rising outside of Board and Senate that threatened their eclipse. The faculty associations now realized that the crucial decisions affecting the university were being made on provincial level, and they sought and gained influence there. They also realized that the Board could not cope adequately with the intricate priorities of expansion, and with the increasing complexities of faculty appointments, promotions, and tenure; they sought representation on the Board, not unfortunately granted, but given indirect recognition through this membership on an intermediary advisory body known as the President's Council. The faculty salary committee was strengthened and pressed its case with great vigour. (The administration welcomed this although it was unhappy about serious suggestions that, in the event of disagreement, an outside arbitrator should be brought in. It seemed to me that the autonomy of the university depended upon its success in resolving ultimate budget problems by its own governing body.) The official student association was even more clamorous; its specific aims in university government were often lost in the energy of protest and in the espousal persistent and more seasoned than the faculty, and they clung tenaciously to one idea that finally triumphed - openness in university government.

In this atmosphere it was evident that the Board established by the Act of 1906 could no longer command authority in the University and that the president could no longer see his role as being "amenable in all respects to their supervision". It seemed to me that both the president and the final governing body should find a new centre; a university without cohesiveness and without the recognition of a source of authority would rapidly lose its autonomy. I thought it was also evident that central authority should be representative of the whole university, and that the president should be its choice and its principal spokesman. After two years of dicussion, in a commission, in bodies throughout the University, and in a university-wide committee, which was a sort of constitutional assembly, the university miraculously agreed on the composition of a central university body. Unfortunately later modifications by government edict disturbed the hard-won compromises, and made implementation difficult. But the three days in June 1970 in which the nature and composition of the new governing body were hammered out in intense, responsible, and good humoured debate, by a body of 160 people representative of the whole university, showed the university at its triumphant best; this seemed to me to demonstrate that the 
university was the place where wide participation in government was both desirable and possible.

The formation of a representative body of final and undisputed power has released the president to seek his authority in the whole university, not in one part of it. The political freedom outside is now balanced by political freedom inside. But the role is not thereby made easier. The president is released only to face new problems perhaps more grievous than those that rocked the turbulent sixties, large among them, provincial policies of financial constraint, and a certain public cynicism about universities. He must still rely upon the same resources, a unified university, not easy to achieve, and a sympathetic public, always elusive. And, as always, the president must maintain the tension - a healthy tension - between the University and Government, between those who put intellectual goals first and those who make economic security the end of their endeavours. In his insistence that the good society will always give high priority to those intellectual goals, the president finds that his responsibilities as politician and his responsibilities as academic are one and indivisible. 